\title{
Assessment of Physical Activity of Children and Youth in Podkarpackie Voivodeship
}

Sabina Krupa ( $\nabla$ sabinakrupa@o2.pl )

Rzeszow University https://orcid.org/0000-0002-3002-3153

Dorota Ozga

Rzeszow University

\section{Patryk Stokłosa}

Science Club Rzeszow University

\section{Research}

Keywords: Physical activity, Children, Youth

Posted Date: January 13th, 2020

DOI: https://doi.org/10.21203/rs.2.18829/v2

License: (c) (1) This work is licensed under a Creative Commons Attribution 4.0 International License. Read Full License 
The authors have withdrawn this preprint from Research Square 